\title{
Rent Seeking and Regional Integration Agreements
}

\author{
Preliminary draft
}

\author{
Samuel Standaert \\ Department of General Economic \\ Ghent University \\ Ghent, Belgium \\ samuel.standaert@gmail.com
}

Glenn Rayp

\begin{abstract}
This paper explores the motives behind the formation of intra-African regional integration agreements (RIAs). We aim to see whether rent seeking can be identified as a statistically significant driving force of African integration. The traditional reason for economic integration, the static and dynamic effects, predict no, or even a negative effect on welfare. Moreover, many of the new regionalism theories are conditional on strong economic integration. Rent seeking behavior and the regime boosting hypothesis are two exceptions. Not only can they credibly explain the proliferation of African trade agreements in the absence of a positive effect on welfare, they can also explain the lack of progress in clearing away the many obstructions to regional trade. However, in spite of the anecdotal evidence, we cannot find convincing evidence that rent seeking behavior has been a motive for African integration. Corruption is insignificant, regardless of the way of testing, or the corruption indicator used. The factors that seem to explain African integration are all geographical, not economic nor political.
\end{abstract}

\section{Keywords Regional Integration; Rent seeking; Africa.}

\section{INTRODUCTION}

Regional integration has been very popular in Africa over the last 50 years. Every country is part of at least one regional integration agreement (RIA), and on average an African country is member of four agreements [1]. Yet, it is hard to reconcile this enthusiasm for regional integration with its results. Practically all indicators (apart from the number of agreements) show that African economies are barely integrated at all. Tariff reduction schemes are backlogged, rules of origin are extremely restrictive and cross-border transportation facilities are either inadequate, or missing altogether. As a result, the level of intra-regional trade of most RIAs barely exceeds the $10 \%$ (relative to around half of all trade in NAFTA or the EU-27), and in some cases it even fell after singing the agreements [2].

What is especially confusing is that the reasons for African integration have never been very compelling to begin with. First of all, most African countries do not produce any of the products that are of interest to neighboring countries. The bulk of African trade is with developed economies, in particular with the European Union. The African trade patterns are not complimentary and static analysis warns that integration will most likely result in trade diversion and hence lower welfare.

The dynamic effects of RIAs are also unlikely to be strong. Creating a unified African market means circumventing or breaking down many barriers to trade: a deficient transportation network, different legal systems, different languages... even in the best case scenario, the costs of unifying these markets outweigh the benefits in the short and mediumlong term [3]. African integration has been found to have no effect on intra-African trade [4], and studies that did find an effect concluded that any increases were driven by trade diversion [5 and 6]. Berthelon [7] concluded that in the best case, integration among developing countries only raises the growth rate of the biggest country. All of this makes it difficult for traditional economic theory to explain the proliferation of African free trade agreements. Similarly, most of the theories lumped together under the banner of new regionalism lack persuasiveness. Locking in reform, raising policy credibility, enhancing regional cooperation, strengthening regional stability all require strong economic integration, or are impeded by the lack thereof [8].

The rent seeking hypothesis and rent seeking behavior are two exceptions. They can account for the strong interest in integration in the absence of a positive effect on welfare, as well as for the failure in breaking down any of the barriers to trade. The regime boosting hypothesis states that governments in a tenuous political position will use the act of signing RIAs as a way to gain legitimacy abroad and attract funding [9]. Regional integration can also be used to set up domestic rent extracting mechanisms. The agreements bestow extensive powers on the negotiating parties, which combined with the absence of an increase in welfare creates an ideal environment for lobbying and bribery.

While there exist ample examples of RIAs misused in this way, the evidence of rent seeking being a driving force of integration remains largely anecdotal. The goal of this paper is to see whether rent seeking can be identified as a statistically significant influence on the decision to enter a free trade agreement in Africa. In doing so, it builds on papers by Mansfield, Milner, and Rosendorff [10], Baier and Bergstrand [11], Endoh [12], Wu [13] and Márquez-Ramos, MartínezZarzoso, and Suárez-Burguet [14] that try to determine the 
reasons behind the formation of regional integration agreements.

This paper differs from those listed above mainly in two ways. Firstly, the focus of this paper is intra-African integration attempts and problems that are particular to this continent. Secondly, with the exception of $\mathrm{Wu}$ [13], the papers above study regional integration in a bilateral setting, focusing on agreements between country pairs. However, the structure of African RIAs does not lend itself to be analyzed in this way since most agreements involve more than two partner countries. Moreover, the bilateral approach ignores the problem of overlapping agreements. As a solution, we propose using a multilateral approach: regressing whether or not country $x$ is member of agreement $z$ on the characteristics of both. It means looking at integration from the point of view of individual country trying to decide whether to join a certain RIA.

\section{RENT SEEKING AS A DRIVING FORCE OF INTEGRATION}

In the regime boosting hypothesis the government's main worry is strengthening its political power. By attending regional summits, singing protocols, etc., the government seeks recognition of its legitimacy abroad, which it then uses to attract foreign aid and support. For example, in SADC ${ }^{1}$ national projects were often disguised as regional ones and got funded with donor money [9].

Besides capturing international rents, RIAs can also be used to appropriate domestic rents. They have a big impact on a substantial part of the economy, and their negotiations bestow extensive powers to politicians and bureaucrats. They can be used to influence market structure, conditions that have to be met to import or export goods, etc. Furthermore, the complexity of the agreements allows corrupt officials to easily hide their actions. This combined with the near zero-sum-game outcome of integration creates an ideal breeding ground for political lobbying, corruption and bribery.

Take for example ECOWAS ${ }^{2}$, where the regional cooperation tax had been set up to compensate countries for the loss of tariff revenues on intra-regional trade. The system set up turned out to be highly discriminatory, providing opportunities only for firms working in the formal sector. It also led to fraudulent behavior because the compensation computations were based on highly unreliable data [15].

A similar situation could be found in $\mathrm{UDEAC}^{3}$ with the single tax (tax unique). The official goal of this tax was to foster and protect intra-regional production by limiting domestic and import taxes relative to extra-regional goods. Selected goods from membership countries were taxed once when crossing the border at their respective single tax rate and would then be exempt from all other indirect taxes and import duties. Again, this set up resulted in an extremely discriminatory system, where not only each firm, but also each good within a firm could be subject to its own tax rate. As a result, the setting of each tax rate was subject to numerous

\footnotetext{
${ }^{1}$ Southern African Development Community

${ }^{2}$ Economic Community of West African States

${ }^{3}$ Central African Monetary and Customs Union
}

strategic considerations and had little to do with economic logic [16].

Rent seeking is also used as an explanation for the lack of progress in regional integration. Vested interests in the informal economy -which often surpasses national boundariesoppose formal treaties that would undo many of the transnational inefficiencies and disparities that are lucrative to them [9]. However, given the potential for profitable opportunities, rent seeking can just as well be a force driving integration agreements. Grossman and Helpman [17] work out a model where the sectors that stand to lose and those that stand to gain both lobby the government and seek to influence its policy decision using political contributions. They find that even in situation were the net effect on welfare is zero or negative, a RIA is a politically feasible option if the level of corruption is high enough. However, the effect of corruption will depend on the relative size of the country.

Ornelas [18] expands the model of Grossman and Helpman by adding a rent-destruction effect. He argues that RIAs lead to more competition between countries, which reduces the returns to high external tariffs for the import competing industries. Because lobbies take this into account when deciding whether or not to support a FTA, the viability of welfare-reducing free trade agreements is severely impaired. The higher the government's preference for rents, the stronger this rentdestruction effect will play. As a result, welfare-reducing RIAs are only possible at intermediate levels of corruption. If social welfare were the only thing of importance, the government would never consider closing welfare-reducing FTAs. With high preference for rents the rent-destruction effect dominates and lobbies would not support the FTA.

Maggi and Rodríguez-Clare [19] see RIAs purely as a way for the government to limit the power of lobbies and eliminate certain sources of rents. In their model, the preference of the government for contributions versus welfare also has a nonmonotonic effect on the likelihood of entering into an agreement. The government would only join a RIA if they care about welfare as well as rents. If they care too much about rents, they would never consider entering into an agreement. On the other hand, if the government was not concerned about rents at all the lobbies wouldn't be able to exert any pressure to start with.

Endoh [12] works out a model detailing the effect of changes in the quality of governance on the formation of RIAs and tests its implications. While his model is also based on Grossman and Helpman [17], the effect of a change in governance is reversed: better governance raises the probability of closing a RIA. The main reason for this is that he uses a different government objective function; Arguing that the inability to tax is also a sign of weak governance, import tariffs are treated the same as contributions for lobbyists. Nevertheless, the effect of governance on the willingness to enter an agreement is not parameter independent and its sign is unclear.

Following Mansfield et al. [10] and Baier and Bergstrand [11], Endoh tests his hypotheses in a strict bilateral setting. A dataset of over 6000 country-pairs is compiled, listing whether or not those countries are in a RIA and a number of shared 
characteristics: combined GDP, difference in GDP, sum of the governance indicators, on what continent both countries lie, etc. Using this dataset in logit regressions, he finds confirmation of the posited positive effect of quality of governance on the likelihood of closing a RIA.

$\mathrm{Wu}$ [13] examines the determinants of deep regional integration. To do this, she creates a variable listing the deepest level of integration a country is engaged in per year . Using a ordered probit estimation procedure, this variable is then regressed on measures of trade, political, business, and price uncertainty and various other country specific characteristics.

As one of the measures of political uncertainty, she uses corruption, reasoning that countries marked by high corruption will use RIAs "to end trade risks brought about by the capricious behavior of domestic government representatives" [13, p.167]. In other words, she posits a positive correlation between corruption and the level of integration. Regressing the latter on Transparency International's corruption perceptions index produces a coefficient with the right sign, but it is small and insignificant. However, when she subsequently collapses the dependent variable to a dummy variable, the coefficient on corruption rises both in absolute value and in significance.

While these results reject Wu's premise, they fit within the rent seeking hypothesis. According to the latter, government officials use RIAs to attract and extract rents, leading to more agreements. However, they oppose deep integration since that might cut of their access to certain sources of rents. Combining both leads to a non-linear effect of corruption on the level of integration, but a positive effect on the number of agreements.

Our paper differs from those above in a number of ways. First of all, it is centered on African integration and focuses on issues common to African RIAs that may be less present elsewhere. The second difference is the way RIAs are analyzed, which is discussed in the next section.

\section{ECONOMETRIC SPECIFICATION}

Two econometric approaches have been used to determine what factors drive regional integration attempts. Mansfield et al. [10], Baier and Bergstrand [11], Endoh [12] and MárquezRamos et al. [14] use a bilateral approach. This entails regressing whether or not two countries have formed a RIA on a number of shared characteristics of both countries. For example, it allows you to test whether differences in level of development or the distance between the two of them will influence the decision to form a RIA.

The drawback of the bilateral approach is that normally only shared characteristics can be taken into account. The characteristics of the countries themselves or those of other partner countries are left out. The last one is especially problematic in the context of African integration, where multilateral RIAs are the norm. Treating these as if they collection of bilateral agreements is a vast oversimplification. For example, it implies that you analyze the decision of Rwanda and Burundi to join the CEPGL ${ }^{4}$, while disregarding the fact that the Democratic Republic of Congo is also a partner

\footnotetext{
${ }^{4}$ CEPGL $=$ Economic Communityof the Great Lakes.
}

in the agreement. Furthermore, the bilateral approach has no way to deal with overlapping agreements, a problem that is endemic in African integration.

$\mathrm{Wu}$ [13] on the other hand uses a unilateral approach: she regresses whether or not country $x$ entered a RIA in year $t$ on the characteristics of that country in that year. This can be used for example to test whether landlocked nations or relatively more corrupt governments are more likely to join a RIA. The main drawback is that the characteristics of the partner countries cannot be taken into account.

The multilateral approach solves the omitted variable bias of both approaches. Instead of looking at country-country pairs like the bilateral approach, it studies country-RIA pairs instead. The dependent variable is a dummy variable indicating whether or not a certain country $x$ is a member of RIA $z$ and can be regressed on information that is country-specific, RIA-specific or both. It can be used to regress the decision to enter a RIA on the average size of member countries, the level of corruption in the candidate country or the fraction of countries with a similar colonial history.

\section{DATA}

\section{A. Regional Integration}

In order to test the link between corruption and integration, data was collected on the founding of, and accession to regional integration agreements in Africa. This was done using the Regional Integration Knowledge System [2], and the webpages of the regional trade agreements themselves. The thirteen FTAs and customs unions incorporated are: AMU, CEN-SAD, ECOWAS, GAFTA and UEMOA in the West and North of Africa; CEPGL, UDEAC, ECCAS, EAC in central Africa; and COMESA, SACU, RIFF and SADC and in the South and East of Africa ${ }^{5}$. Taken together, they cover 53 African countries.

This dataset was used to create three dependent variables to be used in the unilateral, bilateral and multilateral regressions, respectively:

- RIAuni $i_{x, t}$ indicates whether country $x$ signed an agreement in year $t$ or any of the previous four years;

- RIAbi $i_{x, y}$ signals if country $x$ and country $y$ are currently members of the same agreement;

- RIAmulti $i_{x, z}$ shows whether county $x$ has joined RIA $z$.

\section{B. Explanatory variables}

Several control variables are taken into consideration. Most of them come from the aforementioned papers studying the determinants of regional integration. They can be divided into three groups: political, geographical or economic.

There are six geographical variables:

- Landlocked is expected to have a positive sign, since the countries that are cut off from the world markets would be

\footnotetext{
${ }^{5} \mathrm{AMU}=$ African Maghreb Union; CEN-SAD = Community of SahelSaharan States; GAFTA = Greater Arab Free Trade Area; UEMOA = West African Economic and Monetary Union; UDEAC = Customs and Economic Union of Central Africa; EAC = East African Community; SACU = Southern African Customs Union and RIFF = Regional Integration Facilitation Forum
} 
more willing to close RIAs. In the bilateral regressions there are two landlocked variables: landlocked (either) is one if at least one of the countries is landlocked; landlocked (both) when both of them are.

- Island is included because it is found to have a significant negative influence on the decision to enter RIAs in Wu [13].

- SSA indicates if a country lies in Sub Saharan Africa.

- The remaining three geographical variables are indicators of the distance between countries. For each variable, we expect that the closer the countries are, the stronger their inclination to form a RIA is. In the bilateral regressions, adjacency indicates whether the two countries neighbor one another. In the multilateral regressions, it expresses if the country neighbors any members of the RIA. Natural is the inverse of the distance between capitals of the country pair. In the multilateral regressions it is replaced by the minimum distance to the capital of any member of the RIA.

There are two types of economic variables:

- The first economic variable is the difference in the capital/labor ratios between countries ( $K / L$ diff). The bigger the difference, the higher the expected trade creation effects, and the more likely an agreement is. To control for endogeneity we use the capital/labor values of 1981. The data comes from the Extended Penn World Tables [20].

- The other economic variables are GDP and $G D P /$ capita, which come from the World Development Indicators. They are included to capture two conflicting effects. On the one hand, the smaller a country is, the bigger the potential advantages to scale are. On the other hand, the distributional effects of RIAs imply that large countries (hegemonies) stand to gain more.

Five political variables are taken into consideration:

- We have three subjective indicators of corruption at our disposal: Control of Corruption $(\mathrm{CoC})$ produced by the World Bank [21], Transparency International's Corruption Perceptions Index $(C P I)$ and the International Country Risk Guide's index of corruption (ICRG). A high value corresponds to low levels of corruption. For the sake of comparability, they are rescaled to lie between -1 and 1 . Some regressions also incorporate the difference in, average of, or squared levels of corruption (respectively $\mathrm{CoC}$ diff, $\mathrm{CoC} a v$ and $\mathrm{CoC}^{2}$, etc.).

- In the bilateral regression, colony is a dummy variable that is one when the countries have the same colonial background. In the multilateral regressions, it represents the fraction of countries in the RIA with the same colonial background. Colonial history also serves as a proxy for the official language of a country.

- Polity indicates the level of democracy versus autocracy in a country: -10 being a completely totalitarian regime and 10 a completely democratic one. Mansfield et al. [10] find that it has a positive effect on the likelihood to enter a RIA. The data comes from the Polity IV dataset [22].

- GATT/WTO is a dummy variable indicating when a country joined a RIA and is used in the unilateral regressions.

- Openness, the last political variable, is measured as the fraction of exports and imports to GDP. Wu [13] uses it to control for the fact that the more open a country is, the more the government would be willing to stabilize trade flows using RIAs.

\section{EMPIRICAL RESULTS}

\section{A. Unilateral analysis}

In the unilateral analysis RIAuni is regressed on the average value of corruption in the preceding five years and a number of controlling variables (table 1). The model was estimated using a random effects logistic estimator, but the results remain the same when estimated with a simple logistic model.

Since high values of the indicators correspond with low levels of corruption, the rent seeking hypothesis and regime boosting hypothesis predict negative signs for these variables. While CoC and CPI both have negative coefficients, those of ICRG are positive. However, none of them are significant even at the $10 \%$ level. Including the squared values of corruption raises the values of all coefficients. In keeping with what Ornelas (2005) predicts the squared values are positive, but all the corruption variables remain insignificant.

The coefficients of the controlling variables follow a similar pattern: most of them are insignificant, and a lot of them have signs that run counter to what was expected. The only two significant variables are per capita GDP and SSA: more development countries are significantly less likely to join RIAs, as are Sub Saharan countries.

\section{B. Bilateral analysis}

We estimate the effect of corruption in two different ways in the bilateral regressions. In the first, RIAbil is regressed on the level of corruption both countries, similar to how Mansfield et al. [10] controls for the level of democracy. The underlying assumption is that an increase in corruption has the same effect regardless of the level of corruption of the potential partner country. The second approach is the one used by Baier and Bergstrand [11] and Endoh [12] and entails regressing RIAbil on the average level of corruption in both countries. It assumes that the total level of corruption in both countries is of importance, regardless of the individual levels. As an additional explanatory variable, the difference in corruption is also included.

The model is estimated using a logistic regression, with the standard errors corrected for non-nested two-way clustering at the country level (table 2). This is implemented using a procedure outlined in Cameron, Gelbach, and Miller [23].

To control for endogeneity only predated values are used. Two exceptions are CoC and CPI, which are only available since the mid nineties. Moreover, to avoid the selection bias problems the CPI values of 2007 are used, since this is the first year where the index is available for every African country.

This time, ICRG and CoC have a negative sign, while CPI's coefficient is positive. Like in the unilateral regressions, none of them are significant. Using the average corruption levels instead does not change this. The only variable that has a consistent sign for all three corruption variables is the absolute difference in corruption between the two countries: the higher it is, the lower the likelihood that the countries are members of 
the same RIA. Nevertheless, the variable is only significant when the ICRG index is used.

The main variable that explains why some countries are in a RIA together is their distance from each other. Natural (the inverse of the distance between them) is positive and significant at the $1 \%$ level and adjacency is significant at $10 \%$ when using the ICRG index. The only other controlling variable that is significant (at 10\%) is the difference in the capital-labor ratios. However, contrary to what is expected and to what is found in other papers its coefficient is negative. This means that those countries that are less likely to have trade creating effects from RIAs are more likely to be in a RIA. A possible explanation for this aberration is that we are ignoring the influence of other partner countries. If a lot of countries with roughly the same capital-labor ratios have joined a RIA to facilitate trade with a country whose capital ratio does differ, this would bias the coefficient downwards. If so, the multilateral analysis should resolve this inconsistency.

\section{Multilateral regressions}

The multilateral framework combines both the unilateral and bilateral analyses, regressing whether or not a country is a member of a certain RIA on the characteristics of that country and the agreement. Because the composition of some RIAs has changed over time (SADC and COMESA among others), it is important to use the characteristics of the RIA at the time of joining in order to make the correct comparison.

Take for example the average GDP of a RIA. If a certain country $x$ is a member of the RIA, the average is computed over all members of the RIA at the time of joining, excluding $x$. On the other hand, if $x$ has never been a member, the average is computed over all countries that are, or have been a member. The same rule was applied when computing the minimum distance to a member of the agreement, whether a country is adjacent to a member, the average level of corruption, the fraction of countries with a the same colonial history, the average difference in capital-labor ratios and average difference in corruption. Similar to the bilateral analysis, standard errors are corrected for non-nested clusters: on country level and on RIA level (table 3). To avoid problems of endogeneity, predated values are used when possible.

Once again, the signs of the coefficients on the level of corruption in a country are not stable. Both ICRG and CoC now have positive signs, while CPI's is negative. The only corruption variable with a consistent sign is the difference in corruption. The interpretation of this variable differs slightly from that of the bilateral regressions, because the difference is computed in levels and not in absolute values. Its positive sign means that for a given level of corruption in country $x$, the higher corruption in the (other) member countries is, the higher the probability that the country $x$ will join the RIA. However, it is only significant for the CoC index.

The distance between countries remains an important factor in trying to explain African integration, in particular whether a country is adjacent to (other) members of agreement. Sub Saharan African countries are significantly less likely to enter into a RIA, while island nations are more likely. While the difference in capital-ratios is still negative, it has become insignificant, resolving in part the aberration found in the bilateral regressions.

\section{CONCLUSION}

This paper explores the motives behind the proliferation of regional integration agreements in Africa. Static and dynamic analyses predict high welfare reducing effects, and most new regionalism theories rely on strong economic integration. Rent seeking behavior and the regime boosting hypothesis on the other hand can theoretically explain both the growth of African agreements as well as their lack of progress in liberating intraAfrican trade. They state that governments will use trade agreements to gain access to national and international sources of rents, making RIAs politically feasible even when the effect on social welfare is negative.

Empirical evidence of corruption as a driving force has been mostly anecdotal, and the goal of this paper is to find out whether it could be identified as a statistically significant factor. This estimated in three ways: unilaterally, from the point of view of an individual country; bilaterally, looking at agreements between pairs of countries; and multilaterally, studying the reasons for a country to join a particular RIA.

However, we cannot find convincing evidence that corruption has been a driving force of African integration. The signs on the coefficients of corruption change depending on the estimation model, and all but a few of them are insignificant. The only determinants of African integration that can be identified are geographical ones. The closer countries are, the higher the probability they are members of the same RIA. The same holds for countries that lie in Northern Africa and island nations. Economic and political factors on the other hand do not seem to play a role. A result that stands in stark contrast with the predictions of theoretical models [12, 17, 18 and 19], and with world-wide empirical studies where all three factors have been found to play a role [10,11, 12, 13 and 14].

For future research it would be interesting to see whether the relative size of a country influences the effect of corruption on the willingness to close RIAs, as Grossman and Helpman [17] predict. Moreover, the current tests did not take into account the possibility that the effect of corruption is non-linear (cf. [18] and [19]).

\section{ACKNOWLEDGMENT}

I am indebted to prof. dr. Aniruddha Dasgupta and prof. dr. John R. Harris for helping me write this paper. Furthermore, I would like to thank the Special Research Fund of Ghent University and the Belgian American Educational Foundation for their financial support.

\section{REFERENCES}

[1] The World Bank. Global Economic Prospects: Trade, Regionalism, and Development. The International Bank for Reconstruction and Development, Washington (DC), 2005.

[2] UNU-CRIS. Regional integration knowledge system, 2006. URL http://www.cris.unu.edu/riks/web. United Nations University, Comparative Regional Integration Studies.

[3] A. J. Yeats. What can be expected from African regional trade arrangements? The World Bank, WBPR Working Paper 2004, 1998. 
[4] F. Foroutan. Regional integration in Sub-Saharan Africa: Past experiences and future prospects. Cambridge University Press, Cambridge, England, 1993.

[5] C. Carrere. African regional agreements: impact on trade with or without currency unions. Journal of African Economies, 13(2), 2004.

[6] Y. Yang and S. Gupta. Regional trade arrangements in africa: Past performance and the way forward. African Development Review, 19(3):399\{431, 2007.

[7] M. Berthelon. Growth effects of regional integration agreements. Central Bank Of Chili., CBC Working Paper 278, 2004.

[8] A. L. Winters. Post-lomé trading arrangements: The mulitlateral alternative. Kluwer Academic, The Netherlands, 2001.

[9] F. Söderbaum. The Political Economy of Regionalism: The Case of Southern Africa. Palgrave Macmillan, 2004.

[10] D. Mansfield, H. V. Milner, and B. P. Rosendorff. Why democracies cooperate more: Electoral control and international trade agreements. International Organization, 56(3):477-513, 2002.

[11] S. L. Baier and J. H. Bergstrand. Economic determinants of free trade agreements. Journal of International Economics, 64(1):29 - 63, 2004

[12] M. Endoh. Quality of governance and the formation of preferential trade arrangements. Review of International Economics, 14(5):758-772, 2006.

[13] J. P. Wu. Measuring and explaining levels of regional economic integration. Rout- ledge, 2006.

[14] I. Márquez-Ramos Martínez-Zarzoso and C. Suárez-Burguet. Determinants of deep integration: Examining socio-political factors. Open Economic Review, September 2009.
[15] A. M'Bet. The ceao and uemoa within ecowas: The road ahead towards west african economic integration. St. Martin's Press, Inc., New York, NY, 1997.

[16] B. Decaluwe, D. Njinkeu, and J. Cockburn. A udeac case-study. St. Martin's Press, Inc., New York, NY, 1997

[17] G. M. Grossman and E. Helpman. The politics of free-trade agreements. The American Economic Review, 85(4):667-23, 1995.

[18] E. Ornelas. Rent destruction and the political viability of free trade agreements. The Quarterly Journal of Economics, pages 1475-1506, November 2005.

[19] Maggi and A. Rodríguez-Clare. The value of trade agreements in the presence of political pressures. Journal of Political Economy, 106(3):574-601, June 1998

[20] Marquetti. Extended penn world tables, 2008.URL http://homepage.newschool.edu/ foleyd/epwt/

[21] Kaufmann, A. Kraay, and M. Mastruzzi. The worldwide governance indicators - methodology and analytical issues. The World Bank, September 2010.

[22] INSCR. Polity IV: Regime authority characteristics and transitions datasets, 2010. URL http://www.systemicpeace.org/polity/polity4.htm

[23] A. C. Cameron, J. B. Gelbach, and D. L. Miller. Robust inference with multi-way clustering. Working Papers 99, University of California, Davis, Department of Economics., 2006

Table 1 - Unilateral regressions

\begin{tabular}{|c|c|c|c|c|c|c|}
\hline & (1) & (2) & (3) & (4) & (5) & (6) \\
\hline \multirow[t]{2}{*}{ Landlocked } & 0.1089 & -0.0482 & -0.8269 & -0.665 & -0.5773 & -0.6606 \\
\hline & $(0.3897)$ & $(0.3664)$ & $(0.5665)$ & $(0.4879)$ & $(0.6766)$ & $(0.6218)$ \\
\hline \multirow[t]{2}{*}{ SSA } & -0.9286 & -0.8049 & -2.383 & -2.3229 & -3.7994 & -3.8704 \\
\hline & $(0.5442)^{*}$ & $(0.5181)$ & $(1.0239)^{* *}$ & $(0.8759) * * *$ & $(1.3454)^{* * * *}$ & $(1.2135)^{* * *}$ \\
\hline \multirow[t]{2}{*}{ Island nation } & 0.9888 & 0.5071 & -0.726 & -0.4324 & 0.9372 & 0.7013 \\
\hline & $(1.0029)$ & $(0.8948)$ & $(1.3439)$ & $(0.9101)$ & (1.6940) & (1.1171) \\
\hline \multirow[t]{2}{*}{ GDP/cap } & -0.108 & -0.1046 & -0.3084 & -0.2794 & -0.4149 & -0.4148 \\
\hline & $(0.0734)$ & $(0.0707)$ & $(0.1385)^{* *}$ & $(0.1261)^{* *}$ & $(0.2066)^{* *}$ & $(0.1963)^{* *}$ \\
\hline \multirow[t]{2}{*}{ GDP growth } & -0.036 & & -0.0822 & & -0.1234 & \\
\hline & $(0.0490)$ & & $(0.0834)$ & & $(0.1208)$ & \\
\hline \multirow[t]{2}{*}{ Polity II } & 0.0183 & 0.0037 & 0.0127 & 0.0215 & 0.0789 & 0.0868 \\
\hline & $(0.0333)$ & $(0.0307)$ & $(0.0560)$ & $(0.0479)$ & $(0.0748)$ & $(0.0646)$ \\
\hline \multirow[t]{2}{*}{ GATT/WTO } & -0.1093 & & -0.8299 & & -0.4003 & \\
\hline & $(0.4048)$ & & $(0.6986)$ & & (1.0794) & \\
\hline \multirow[t]{2}{*}{ Openness } & 0.1722 & & -0.3941 & & -0.4318 & \\
\hline & $(0.4470)$ & & $(0.5235)$ & & $(0.6866)$ & \\
\hline \multirow[t]{2}{*}{ ICRG } & 0.2639 & 0.5006 & & & & \\
\hline & $(0.5362)$ & $(0.5362)$ & & & & \\
\hline \multirow[t]{2}{*}{$\mathrm{ICRG}^{2}$} & & 0.3238 & & & & \\
\hline & & $(0.8960)$ & & & & \\
\hline \multirow[t]{2}{*}{$\mathrm{CoC}$} & & & -0.4150 & -0.1840 & & \\
\hline & & & (1.0608) & (1.5487) & & \\
\hline \multirow[t]{2}{*}{$\mathrm{CoC}^{2}$} & & & & 0.8495 & & \\
\hline & & & & $(2.2485)$ & & \\
\hline \multirow[t]{2}{*}{ CPI } & & & & & -2.014 & 2.1753 \\
\hline & & & & & $(2.1762)$ & (4.8703) \\
\hline \multirow[t]{2}{*}{$\mathrm{CPI}^{2}$} & & & & & & 6.015 \\
\hline & & & & & & $(6.5591)$ \\
\hline \multirow[t]{2}{*}{ Constant } & 0.3823 & 0.1744 & 3.2694 & 1.5929 & 3.6303 & 2.8056 \\
\hline & $(0.7512)$ & $(0.5609)$ & $(1.5279)^{* *}$ & $(0.9657)^{*}$ & $(2.4874)$ & (1.7068) \\
\hline Observations & 192 & 209 & 122 & 149 & 90 & 108 \\
\hline $\mathrm{Nr}$ of Countries & 35 & 36 & 44 & 50 & 41 & 50 \\
\hline loglikelihood & -117.52 & -127.6 & -61.7 & -76.73 & -42.43 & -49.6 \\
\hline
\end{tabular}

$*$ significant at $10 \%$; ** significant at $5 \%$; *** significant at $1 \%$ 
Table 2 - Bilateral regressions

\begin{tabular}{|c|c|c|c|c|c|c|}
\hline \multirow{3}{*}{ Adjacent } & (1) & (2) & (3) & (4) & (5) & (6) \\
\hline & 1.1766 & 1.2584 & 0.9014 & 0.9653 & 0.9864 & 1.065 \\
\hline & $(0.6862)^{*}$ & $(0.6793)^{*}$ & $(0.6223)$ & (0.6769) & $(0.6484)$ & $(0.6892)$ \\
\hline \multirow[t]{2}{*}{ Natural } & 127.645 & 127.3523 & 154.3082 & 153.4988 & 163.972 & 163.1013 \\
\hline & $(39.0336)^{* * * *}$ & $(41.1642) * * *$ & $(34.7185)^{* * *}$ & $(34.2681)^{* * * *}$ & $(36.0723) * * *$ & $(35.5971)^{* * *}$ \\
\hline landl. - either & $\begin{array}{r}-0.3799 \\
(0.3647)\end{array}$ & $\begin{array}{r}-0.3203 \\
(0.3433)\end{array}$ & $\begin{array}{r}-0.2679 \\
(0.3194)\end{array}$ & $\begin{array}{r}-0.3376 \\
(0.3133)\end{array}$ & $\begin{array}{r}-0.2752 \\
(0.3062)\end{array}$ & $\begin{array}{r}-0.3348 \\
(0.3031)\end{array}$ \\
\hline \multirow[t]{2}{*}{ landl. - both } & 0.1045 & 0.1577 & -0.568 & -0.6001 & -0.573 & -0.5931 \\
\hline & $(0.6586)$ & $(0.6307)$ & $(0.4380)$ & $(0.4366)$ & $(0.4107)$ & $(0.4155)$ \\
\hline GDPa & $\begin{array}{r}0.0202 \\
(0.0175)\end{array}$ & & $\begin{array}{r}0.0115 \\
(0.0182)\end{array}$ & & $\begin{array}{r}0.011 \\
(0.0182)\end{array}$ & \\
\hline GDPb & $\begin{array}{r}0.0009 \\
(0.0068)\end{array}$ & & $\begin{array}{r}0.0003 \\
(0.0067)\end{array}$ & & $\begin{array}{r}-0.0022 \\
(0.0070)\end{array}$ & \\
\hline GDP av & & $\begin{array}{r}0.0018 \\
(0.0178)\end{array}$ & & $\begin{array}{r}-0.024 \\
(0.0229)\end{array}$ & & $\begin{array}{r}-0.0217 \\
(0.0209)\end{array}$ \\
\hline GDP diff & & $\begin{array}{r}0.0175 \\
(0.0129)\end{array}$ & & $\begin{array}{r}0.0199 \\
(0.0133)\end{array}$ & & $\begin{array}{r}0.0159 \\
(0.0127)\end{array}$ \\
\hline $\mathrm{K} / \mathrm{L}$ diff & $\begin{array}{c}-0.382 \\
(0.2407) \\
\end{array}$ & $\begin{array}{c}-0.379 \\
(0.2256)^{*}\end{array}$ & $\begin{array}{c}-0.2512 \\
(0.1481)^{*}\end{array}$ & $\begin{array}{l}-0.2278 \\
(0.1555) \\
\end{array}$ & $\begin{array}{c}-0.29 \\
(0.1524)^{*}\end{array}$ & $\begin{array}{c}-0.2729 \\
(0.1523)^{*}\end{array}$ \\
\hline colony & $\begin{array}{r}-0.194 \\
(0.2925)\end{array}$ & $\begin{array}{r}-0.1974 \\
(0.3008)\end{array}$ & $\begin{array}{r}0.39 \\
(0.2588)\end{array}$ & $\begin{array}{r}0.4028 \\
(0.2659)\end{array}$ & $\begin{array}{r}0.3018 \\
(0.2664)\end{array}$ & $\begin{array}{r}0.3215 \\
(0.2651)\end{array}$ \\
\hline ICRG A & $\begin{array}{r}-0.371 \\
(0.5201)\end{array}$ & & & & & \\
\hline ICRG B & $\begin{array}{r}-0.0244 \\
(0.3076)\end{array}$ & & & & & \\
\hline ICRG av & & $\begin{array}{r}-0.806 \\
(0.7541)\end{array}$ & & & & \\
\hline ICRG diff & & $\begin{array}{l}-0.8485 \\
(0.5126)^{*}\end{array}$ & & & & \\
\hline CPI A & & & $\begin{array}{r}-0.854 \\
(0.9495)\end{array}$ & & & \\
\hline CPI B & & & $\begin{array}{r}-0.1875 \\
(0.9363)\end{array}$ & & & \\
\hline $\mathrm{CPI}$ av & & & & $\begin{array}{r}-0.8323 \\
(1.4943)\end{array}$ & & \\
\hline CPI diff & & & & $\begin{array}{r}-0.7209 \\
(1.0297)\end{array}$ & & \\
\hline CoC A & & & & & $\begin{array}{r}0.3414 \\
(0.6436)\end{array}$ & \\
\hline $\mathrm{CoC} B$ & & & & & $\begin{array}{r}0.5315 \\
(0.4802)\end{array}$ & \\
\hline $\mathrm{CoC}$ av & & & & & & $\begin{array}{r}0.8437 \\
(0.7825)\end{array}$ \\
\hline $\mathrm{CoC}$ diff & & & & & & $\begin{array}{r}-0.2995 \\
(0.5223)\end{array}$ \\
\hline Constant & $\begin{array}{r}-15.5359 \\
(4.6943)^{* * *}\end{array}$ & $\begin{array}{c}-15.2836 \\
(4.8560)^{* * *}\end{array}$ & $\begin{array}{c}-19.1885 \\
(4.0100)^{* * *}\end{array}$ & $\begin{array}{c}-18.8033 \\
(3.8999) * * *\end{array}$ & $\begin{array}{c}-19.5578 \\
(4.2541)^{* * *}\end{array}$ & $\begin{array}{c}-19.2959 \\
(4.2065)^{* * * *}\end{array}$ \\
\hline Observations & 561 & 561 & 1081 & 1081 & 1081 & 1081 \\
\hline likelihood & -284.61 & -283.64 & -539.01 & -538.51 & -538.62 & -539.42 \\
\hline
\end{tabular}

(in parentheses) are corrected
Table 3 - Multilateral regression

\begin{tabular}{|c|c|c|c|c|c|c|}
\hline & (1) & (2) & (3) & (4) & (5) & (6) \\
\hline Adjacent & $\begin{array}{c}1.6796 \\
(0.3800)^{* * * *}\end{array}$ & $\begin{array}{c}1.4945 \\
(0.4480) * * *\end{array}$ & $\begin{array}{c}1.6662 \\
(0.3694) * * *\end{array}$ & $\begin{array}{c}1.6514 \\
(0.3698) * * *\end{array}$ & $\begin{array}{c}1.6324 \\
(0.3528)^{* * *}\end{array}$ & $\begin{array}{c}1.6336 \\
(0.3588)^{* * * *}\end{array}$ \\
\hline min Distance & $\begin{array}{c}-0.2743 \\
(0.2620)\end{array}$ & $\begin{array}{l}-0.3904 \\
(0.2400)\end{array}$ & $\begin{array}{c}-0.4564 \\
(0.2032) * *\end{array}$ & $\begin{array}{c}-0.4585 \\
(0.1987)^{* *}\end{array}$ & $\begin{array}{c}-0.4589 \\
(0.2052)^{* *}\end{array}$ & $\begin{array}{c}-0.4479 \\
(0.1976) * *\end{array}$ \\
\hline Landlocked & $\begin{array}{c}-0.2113 \\
(0.5839)\end{array}$ & $\begin{array}{c}-0.0099 \\
(0.7696)\end{array}$ & $\begin{array}{l}-0.0871 \\
(0.4290)\end{array}$ & $\begin{array}{l}-0.0896 \\
(0.4309)\end{array}$ & $\begin{array}{l}-0.0278 \\
(0.4342)\end{array}$ & $\begin{array}{l}-0.0745 \\
(0.4514)\end{array}$ \\
\hline Island & $\begin{array}{c}1.503 \\
(0.9630)\end{array}$ & $\begin{array}{c}1.1695 \\
(0.9873)\end{array}$ & $\begin{array}{c}1.4759 \\
(0.5968)^{* *}\end{array}$ & $\begin{array}{c}1.4487 \\
(0.6113)^{* *}\end{array}$ & $\begin{array}{c}1.6103 \\
(0.5227)^{* * *}\end{array}$ & $\begin{array}{c}1.5189 \\
(0.5534)^{* * * *}\end{array}$ \\
\hline SSA & $\begin{array}{c}-1.0354 \\
(0.5671)^{*}\end{array}$ & $\begin{array}{c}-1.5762 \\
(0.3690)^{* * *}\end{array}$ & $\begin{array}{c}-1.171 \\
(0.5417)^{* *}\end{array}$ & $\begin{array}{c}-1.2171 \\
(0.5469) * *\end{array}$ & $\begin{array}{c}-1.3683 \\
(0.5041)^{* * * *}\end{array}$ & $\begin{array}{c}-1.349 \\
(0.5193)^{* * *}\end{array}$ \\
\hline $\mathrm{K} / \mathrm{L}$ diff & $\begin{array}{c}-0.0185 \\
(0.3367)\end{array}$ & $\begin{array}{l}-0.0203 \\
(0.3170)\end{array}$ & $\begin{array}{l}-0.0774 \\
(0.1725)\end{array}$ & $\begin{array}{l}-0.1005 \\
(0.1828)\end{array}$ & $\begin{array}{l}-0.0203 \\
(0.1668)\end{array}$ & $\begin{array}{l}-0.0638 \\
(0.1836)\end{array}$ \\
\hline GDP & $\begin{array}{c}-0.0262 \\
(0.0398)\end{array}$ & $\begin{array}{c}-0.0227 \\
(0.0407)\end{array}$ & $\begin{array}{l}-0.0117 \\
(0.0256)\end{array}$ & $\begin{array}{l}-0.0137 \\
(0.0263)\end{array}$ & $\begin{array}{c}-0.009 \\
(0.0288)\end{array}$ & $\begin{array}{c}-0.012 \\
(0.0290)\end{array}$ \\
\hline GDP RIA & $\begin{array}{c}-0.0106 \\
(0.0202)\end{array}$ & $\begin{array}{l}-0.0163 \\
(0.0233)\end{array}$ & $\begin{array}{c}-0.019 \\
(0.0162)\end{array}$ & $\begin{array}{l}-0.0186 \\
(0.0161)\end{array}$ & $\begin{array}{l}-0.0184 \\
(0.0161)\end{array}$ & $\begin{array}{l}-0.0186 \\
(0.0160)\end{array}$ \\
\hline Colony & $\begin{array}{c}0.6227 \\
(0.8896)\end{array}$ & $\begin{array}{c}0.4177 \\
(0.7416)\end{array}$ & $\begin{array}{c}0.7931 \\
(0.5630)\end{array}$ & $\begin{array}{c}0.7737 \\
(0.5653)\end{array}$ & $\begin{array}{c}0.8244 \\
(0.5359)\end{array}$ & $\begin{array}{c}0.8445 \\
(0.5351)\end{array}$ \\
\hline Polity & $\begin{array}{c}0.0026 \\
(0.0053)\end{array}$ & $\begin{array}{l}-0.0287 \\
(0.0232)\end{array}$ & $\begin{array}{c}0.0173 \\
(0.0340)\end{array}$ & $\begin{array}{c}0.0168 \\
(0.0338)\end{array}$ & $\begin{array}{c}0.0344 \\
(0.0332)\end{array}$ & $\begin{array}{c}0.0308 \\
(0.0325)\end{array}$ \\
\hline ICRG & $\begin{array}{c}0.0142 \\
(0.4786)\end{array}$ & $\begin{array}{c}0.0452 \\
(0.5994)\end{array}$ & & & & \\
\hline ICRG RIA & $\begin{array}{c}0.5875 \\
(1.1339)\end{array}$ & & & & & \\
\hline ICRG diff & & $\begin{array}{c}0.0053 \\
(0.1290)\end{array}$ & & & & \\
\hline $\mathrm{CoC}$ & & & $\begin{array}{c}0.5019 \\
(0.4094)\end{array}$ & $\begin{array}{c}0.5027 \\
(0.4552)\end{array}$ & & \\
\hline CoC RIA & & & $\begin{array}{l}-0.3032 \\
(0.3705)\end{array}$ & & & \\
\hline $\mathrm{CoC}$ diff & & & & $\begin{array}{c}0.1886 \\
(0.0659)^{* * * *}\end{array}$ & & \\
\hline CPI & & & & & $\begin{array}{l}-0.2705 \\
(0.8213)\end{array}$ & $\begin{array}{l}-0.1118 \\
(0.8509)\end{array}$ \\
\hline CPI RIA & & & & & $\begin{array}{c}-0.4786 \\
(0.1268)^{* * *}\end{array}$ & \\
\hline CPI diff & & & & & & $\begin{array}{c}0.0951 \\
(0.0974)\end{array}$ \\
\hline Constant & $\begin{array}{l}-1.1903 \\
(0.9762)\end{array}$ & $\begin{array}{c}-0.6401 \\
(0.5932)\end{array}$ & $\begin{array}{l}-0.9373 \\
(0.7266)\end{array}$ & $\begin{array}{c}-0.6469 \\
(0.7768)\end{array}$ & $\begin{array}{c}0.4831 \\
(1.2569)\end{array}$ & $\begin{array}{l}-0.7583 \\
(0.9577)\end{array}$ \\
\hline $\begin{array}{l}\text { Observations } \\
\text { loglikelihood }\end{array}$ & $\begin{array}{c}306 \\
-102.86\end{array}$ & $\begin{array}{c}223 \\
-72.4\end{array}$ & $\begin{array}{c}530 \\
-162.62\end{array}$ & $\begin{array}{c}530 \\
-162.48\end{array}$ & $\begin{array}{c}530 \\
-162.41\end{array}$ & $\begin{array}{c}530 \\
-163.28\end{array}$ \\
\hline
\end{tabular}

Gu clusters on country-level and RIA-level (in parenthesis). * significant at 10\%; ** significant at 5\%; *** significant at $1 \%$

$$
\text { significant at } 1 \% \text {. }
$$

